\title{
Does fluorosis have an impact on Peruvian children's oral health related quality of life?
}

\author{
Fluorose dentária tem impacto na qualidade de vida \\ relacionada à saúde bucal de crianças peruanas?
}

\author{
Zaida Moya de CALDERÓN1 1 iD https://orcid.org/0000-0003-2742-5255 \\ Jenny ABANTO2 ${ }^{2}$ iD https://orcid.org/0000-0001-5088-878X \\ Gabriela Sá OLIVEIRA3 iD https://orcid.org/0000-0002-1955-9002 \\ Ana Estela HADDAD3 iD https://orcid.org/0000-0002-0693-9014 \\ Marcelo BÖNECKER ${ }^{3}$ iD https://orcid.org/0000-0001-9786-6473
}

\section{ABSTRACT}

Objectives: The aims of this study were to evaluate the prevalence and severity of dental fluorosis and to assess the impact of dental fluorosis on oral health related quality of life (OHRQoL) of children living in two Peruvian towns with different water fluoride levels. Methods: A sample of 292 children between 11 and 14 years of age and both genders were selected among public and private primary schools in the 2 towns. Clinical oral examination was carried out using Dean's index to assess the prevalence and severity of dental fluorosis and the Child Perceptions Questionnaire 11-14 (CPQ 11-14) was used to evaluate the association between dental fluorosis and OHRQoL. Results: Dental fluorosis prevalence was 75\% and the moderate score was the most frequent (36\%). The two towns have a low socioeconomic level and children from public schools predominate (74\%). There was no impact of fluorosis on OHRQoL. It is possible that adolescents living in a context with very similar dental appearance of their peers build a sense of identity different than other populations, which can influence in their OHRQoL perception. Conclusion: Even though dental fluorosis prevalence was very high it did not have impact on OHRQoL.

Indexing terms: Dental fluorosis. Oral health. Prevalence. Quality of life.

\section{RESUMO}

Objetivos: Os objetivos deste estudo foram avaliar a prevalência e a gravidade da fluorose dentária e avaliar o impacto da fluorose dentária na qualidade de vida relacionada à saúde bucal (QVRSB) de crianças residentes em duas cidades peruanas com diferentes níveis de flúor de água. Métodos: Uma amostra de 292 crianças entre 11 e 14 anos de idade e ambos os sexos foram selecionada nas escolas públicas e privadas de ensino fundamental nas duas cidades. O exame oral clínico foi realizado utilizando-se o índice de Dean para avaliar a prevalência e a gravidade da fluorose dentária e o Questionário de Percepção Infantil 11-14 (CPQ 11-14) para avaliar a associação entre fluorose dentária e QVRSB. Resultados: A prevalência de fluorose dentária foi de 75\% e o escore moderado foi

$\boldsymbol{\nabla} \nabla \boldsymbol{\nabla} \nabla$

1 Universidad Católica de Santa María, Arequipa, Peru.

2 Universitat International de Catalunya, Barcelona, Espanha.

3 Universidade de São Paulo, Faculdade de Odontologia, Departamento de Ortodontia e Odontopediatria. Av. Prof. Lineu Prestes, 2227, 05508-900, São Paulo, SP, Brasil. Correspondence to: M BÖNECKER. E-mail: <bonecker@usp.br>.

$\mathbf{v} \mathbf{v} \boldsymbol{v}$

How to cite this article

Calderon ZM, Abanto J, Oliveira GS, Haddad AE, Bonecker M. Does fluorosis have an impact on Peruvian children's oral health related quality of life?. RGO, Rev Gaúch Odontol. 2021;69:e2021002. http://dx.doi.org/10.1590/1981-8637202100023412 
o mais frequente (36\%). As duas cidades têm baixo nível socioeconômico e predominam as crianças de escolas públicas (74\%). Não houve impacto da fluorose na QVRSB. É possível que os adolescentes que vivem em um contexto social em que a aparência dentária seja muito semelhante entre as pessoas tenham um senso de identidade diferente de outras sociedades, o que pode influenciar em sua percepção de QVRSB. Conclusão: Embora a prevalência de fluorose dentária tenha sido muito alta, não teve impacto na QVRSB.

Termos de indexação: Fluorose dentária. Saúde bucal. Prevalência. Qualidade de vida.

\section{INTRODUCTION}

The use of fluorides has contributed for caries prevalence decrease in the world. [1] Reductions in dental caries experience were recorded in many countries and they were attributable to the widespread use of fluoride [2], therefore they are considered an essential part of oral health programs [3].

On the other hand, in the last decades an increase in dental fluorosis prevalence could be noticed in areas with high, adequate and low fluorides level in public water, and even in areas with no fluoridated water $[4,5]$. However, dental fluorosis mainly occurs when fluorides levels in water exceed the limits established as therapeutic, meaning levels above $1 \mathrm{ppm} / \mathrm{l}$ [6].

Epidemiological studies carried out in different countries showed that dental fluorosis prevalence in children varied from $10.1 \%$ in Peru [6] to $91,9 \%$ in Mexico [7]. However, the prevalence found in Peru does not show the current condition, since the mentioned survey was carried out fifteen years ago.

To date, there are few studies in the world that evaluated the impact of dental fluorosis in OHRQoL [8-10] and none was carried out in Peru due to the fact that there were no validated OHRQoL's instruments in Peru. Meanwhile, the perception questionnaire for children aged 11 to 14 years (CPQ11-14) was translated and validated for the Spanish of Peru. This instrument has satisfactory psychometric properties that can be tested in Peruvian children $[11,12]$. So, it can be applied in Peruvian studies and compared to the results of studies from other countries, cultures and ethnic groups. The main aim of this study was to evaluate the prevalence and severity of dental fluorosis and to assess the impact of dental fluorosis on oral health related quality of life (OHRQoL) of Peruvian children.

\section{METHODS}

A total of 292 children between 11 and 14 years of age and both genders who attended all public and private primary schools were selected. The children were residents of two towns: Congata and Uchumayo near to the city of Arequipa - Peru.

The data were collected from December 2016 until March 2017. Clinical variables were assessed by a trained and calibrated dentist. Kappa intra and inter-examiner was 0.91 and and 0.82 for dental fluorosis, respectively and 0.95 and 0.89 for dental caries.

The present research was approved by the ethics committee of the Faculty of Dentistry of the University of São Paulo.

\section{Geografical data}

Congata has an economically active population dedicated mainly to mining activities. The residents of Uchumayo are simple farmers and miners. Each town has water supply through an individual system called Local Water Administration (ALA), which is responsible for the public drinking water system [13].

An analysis of fluorides level in the water was carried out. Three points to collect water samples were selected in each town. Moreover, at each point three samples of water were colected and each sample was collected in one week interval. Each analysis was done in duplicate. The results showed that in Congata the fluoride concentration was $0.88 \mathrm{ppm} / \mathrm{I}(\mathrm{SD}=0.02)$, and in Uchumayo it was $1.41 \mathrm{ppm} / \mathrm{I}(\mathrm{SD}=0.03)$. In Congata the fluoride level is acceptable (0.88 ppm F) while in Uchumayo (1.44 ppm F) the fluoride level is high. Both towns are located near the city of Arequipa in Peru and have natural fluoride concentration.

\section{Sample}

Sample calculation was based on previous dental fluorosis prevalence in Peru: $10.1 \%{ }^{6}$, design effect of 1.7 and a standard deviation of $5 \%$. Thus, a minimum sample required was 237 children. However to cover the nonresponse rate the sample was increased by $20 \%$, obtaining a final representative sample of 285 children. 
In each town there is only one public school and in Congata there is also one private school. The sample was collected from all two schools. Thus, all children aged 11 to 14 years who were enrolled in all schools in the two towns were invited to participate in the study.

As there was no non-response rate and this study included all children enrolled in the schools of both cities, the final sample was 292 children, which was greater than the minimum sample calculated $(n=285)$.

The parental informed consent was signed and the term of informed consent was given to the students prior to the investigation.

\section{Socioeconomic and OHRQoL data}

Each work session began with an orientation to the students in how to fill the socioeconomic questionnaire which were answered at the same time by all the students at the classroom.

After that, each child was interviewed individually using the Child Perceptions Questionnaire 11-14 (CPQ 11-14). Two interviewers were trained by the principal investigator in the reading and intonation of each question of the questionnaire. This questionnaire has a crosscultural translation, adaptation and validation for the Spanish language used in Peru [2] and was used to assess the impact of dental fluorosis on OHRQoL.

CPQ 11-14 contains 37 items grouped into four subgroups (domains): oral symptoms (6 items), functional limitations (10 items), emotional well-being (9 items), and social well-being (12 items). The questions are related to the frequency of events in the last three months. Response options are presented on a five-point Likert scale: "never" = 0, "one / two times" = 1, "sometimes" = 2, "many times" = 3, "every day / almost every day " $=4$.

The total score of the CPQ 11-14 is calculated as a simple summation of the response codes, as there are 37 questions the total score can vary from 0 to 148 , where the highest score indicates a greater impact of the oral conditions on the OHRQoL.

\section{Clinical examination}

The clinical examination was conducted in a classroom at the school using a table with natural light and disposable wooden spatula. All clinical exams were done by only on dentist that was blinded and not aware of the data in the questionnaires.

In order to diagnosis dental fluorosis, it was used Dean index modified by WHO [14]. All teeth were examined and the final dental fluorosis score was achieved by considering the two most affected teeth. When the two most affected teeth were not similarly compromised, the score of the least affected between the two was recorded. Moreover, in order to diagnosis dental caries, it was used DMFT index described by WHO $[14,15]$.

The socioeconomic variables analyzed were children's age and gender; parents' schooling level, number of siblings and with whom the child lives; public or private school.

\section{Statistical analysis}

All data collected regarding the children examined were entered in a Microsoft Excel program by the researcher herself.

For the statistical analysis the Statistical Package for Social Science Software (SPSS, version 16.0) was used. Initially, descriptive analyzes were performed to obtain measures of central tendency (mean), and dispersion measures (observed variation, standard deviation), as well as total and domain scoring of CPQ 11-14 (OHRQoL).

Univariate and multivariate Poisson regression analysis with robust variance were used to associate the results by domains of CPQ 11-14 (OHRQoL) with socioeconomic conditions, clinical conditions of dental fluorosis and tooth decay. Robust Rate Ratios (RTR) and Confidence Intervals of $95 \%(95 \% \mathrm{Cl})$ were calculated. To enter the final adjusted model, only co-variables with a value of $p<0.20$ will be considered and, in order to be maintained in this model, they should have a value of $p<0.05$.

\section{RESULTS}

The prevalence of dental fluorosis was $75 \%$, of these, $31 \%$, were very mild and mild, 36\% moderate and $8 \%$ severe. It is noteworthy that the scores moderate and severe together were $44 \%$ of the sample (table 1 ). The sample consisted of 11 years-old children (31\%), 12 years-old (24\%), 13 years-old (26\%) and 14 years-old (19\%), with a slight predominance of males 157 (54\%). 
Table 1. Sociodemographics and clinical characteristics of the sample ( $n=292)$, Congata and Uchumayo 2016.

\begin{tabular}{|c|c|}
\hline Variables & n (\%) \\
\hline \multicolumn{2}{|l|}{ Sociodemographic conditions } \\
\hline \multicolumn{2}{|l|}{ Child's age } \\
\hline 11 years old & $91(31.16)$ \\
\hline 12 years old & $69(23.63)$ \\
\hline 13 years old & $76(26.03)$ \\
\hline 14 years old & $56(19.18)$ \\
\hline \multicolumn{2}{|l|}{ Child's gender } \\
\hline Female & $135(46.23)$ \\
\hline Male & $157(53.77)$ \\
\hline \multicolumn{2}{|l|}{ Type of School } \\
\hline Public & $216(73.97)$ \\
\hline Private & $76(26.03)$ \\
\hline \multicolumn{2}{|l|}{ City } \\
\hline Congata & $202(69.18)$ \\
\hline Uchumayo & $90(30.82)$ \\
\hline \multicolumn{2}{|l|}{ Number of siblings } \\
\hline$\leq 2$ children & $109(37.33)$ \\
\hline$>2$ children & $183(62.67)$ \\
\hline \multicolumn{2}{|l|}{ Father's education level } \\
\hline$\leq 6$ years & $49(16.84)$ \\
\hline$>6$ years & $242(83.16)$ \\
\hline \multicolumn{2}{|l|}{ Mother's education level } \\
\hline$\leq 6$ years & $71(24.32)$ \\
\hline$>6$ years & $221(75.68)$ \\
\hline \multicolumn{2}{|l|}{ Family structure } \\
\hline Nuclear family & $196(67.12)$ \\
\hline Non-Nuclear family & $96(32.88)$ \\
\hline \multicolumn{2}{|l|}{ Clinical conditions } \\
\hline \multicolumn{2}{|c|}{$\begin{array}{l}\text { 'Would you say that the health of your teeth, lips, } \\
\text { jajajaws and mouth is. . .?' jaws and mouth is...?' }\end{array}$} \\
\hline Excellent & $13(4.45)$ \\
\hline Very good & $25(8.56)$ \\
\hline Good & $93(31.85)$ \\
\hline Fair & $154(52.74)$ \\
\hline Poor & $7(2.40)$ \\
\hline \multicolumn{2}{|c|}{$\begin{array}{l}\text { 'How much does the condition of your teeth, lips, jaw } \\
\text { jaws or mouth affect your life overall'? }\end{array}$} \\
\hline Not at all & $51(17.47)$ \\
\hline Very little & $68(23.29)$ \\
\hline Some what & $126(43.15)$ \\
\hline A lot & $36(12.33)$ \\
\hline Very much & $11(3.77)$ \\
\hline \multicolumn{2}{|l|}{ Fluorosis prevalence } \\
\hline Absence (normal an questionable) & $73(25.0)$ \\
\hline Presence & $219(75.0)$ \\
\hline \multicolumn{2}{|l|}{ Fluorosis severity } \\
\hline Normal and questionable & $73(25.0)$ \\
\hline Very mild and mild & $91(31.16)$ \\
\hline Moderate & $105(35.96)$ \\
\hline Severe & $23(7.88)$ \\
\hline \multicolumn{2}{|l|}{ Fluorosis sector } \\
\hline Anterior teeth (canine to canine) & $38(13.01)$ \\
\hline Posterior teeth (molar teeth) & $16(5.48)$ \\
\hline Both sectors & $188(64.38)$ \\
\hline \multicolumn{2}{|l|}{ Dental Caries Experience } \\
\hline Absence $(\mathrm{DMFT}=0)$ & $120(41.10)$ \\
\hline Presence (DMFT $\geq 1$ ) & $172(58.90)$ \\
\hline
\end{tabular}

The socioeconomic level is low and $74 \%$ of the students were from public schools. Congata had 202 schoolchildren (70\%) and constitutes the town with greater number of children of the sample. Father and the mother schooling were dichotomized in two categories, predominating those who had more than 6 years of education: $83 \%$ of fathers and $76 \%$ of mothers, which correspond to a secondary education and higher. The number of siblings at home was also dichotomized. $63 \%$ of the parents had more than 2 children. Moreover, most of the children (67\%) lived with their parents in a nuclear family. Dental caries prevalence was high. $59 \%$ of children had at least one decayed, missed or filled tooth.

Table 2 shows the mean, standard deviation and range observed for overall and for each CPQ11-14 domain scores. Table 3 shows the unadjusted analysis of socioeconomic and clinical conditions variables associated with total and individual domains of the CPQ11-14. There was significant association between some independent variables, total scores, and individual domains $(P<0.05)$ : oral symptoms domain and child's age, type of school, mother's education and dental caries experience; functional limitations domain and gender, type of school, mother's education; emotional well-being domain, gender and type of school; social well-being domain and type of school; and total CPQ11-14 scores and gender, type of school and mother's education.

Table 2. Mean, standard deviation and range observed for overall and for each CPQ11-14 domain scores $(n=292)$, Congata and Uchumayo 2016.

\begin{tabular}{lcc}
\hline CPQ11-14 (variances) & Means(SD) & Range Observed \\
\hline Oral symptoms & $6.01(3.16)$ & $0-16$ \\
Functional limitations & $6.16(4.36)$ & $0-26$ \\
Emotional well-being & $7.30(5.96)$ & $0-36$ \\
Social well-being & $5.54(5.91)$ & $0-34$ \\
\hline Total Score & $25.02(15.43)$ & $0-84$ \\
\hline
\end{tabular}

The domain with the highest mean score was the emotional well-being domain (7,30 SD: 5,96), which means that dental fluorosis might influence children's emotions.

The adjusted model (table 4) showed that the increase in child's age and dental caries experience showed a positive and negative impact, respectively, on the 


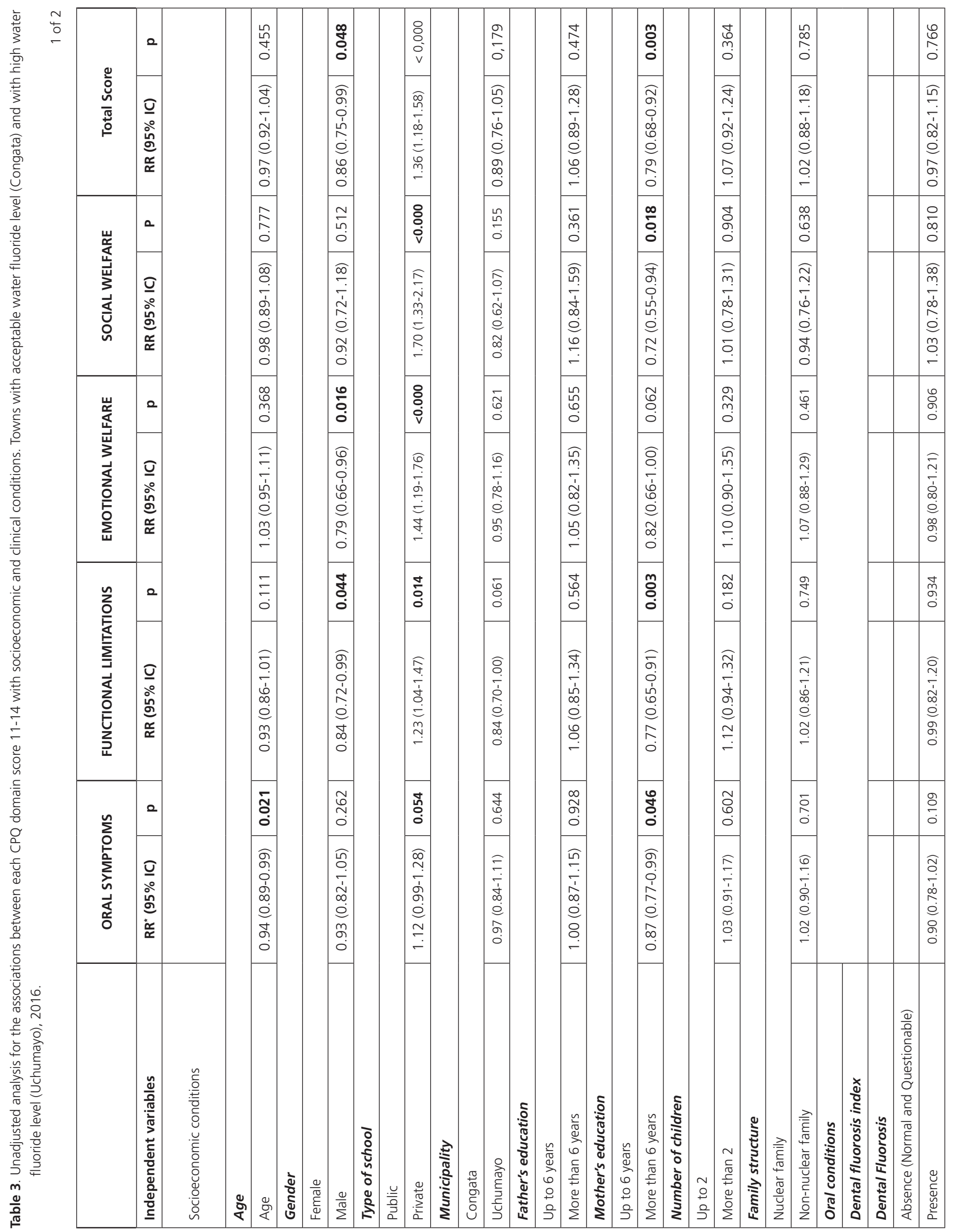




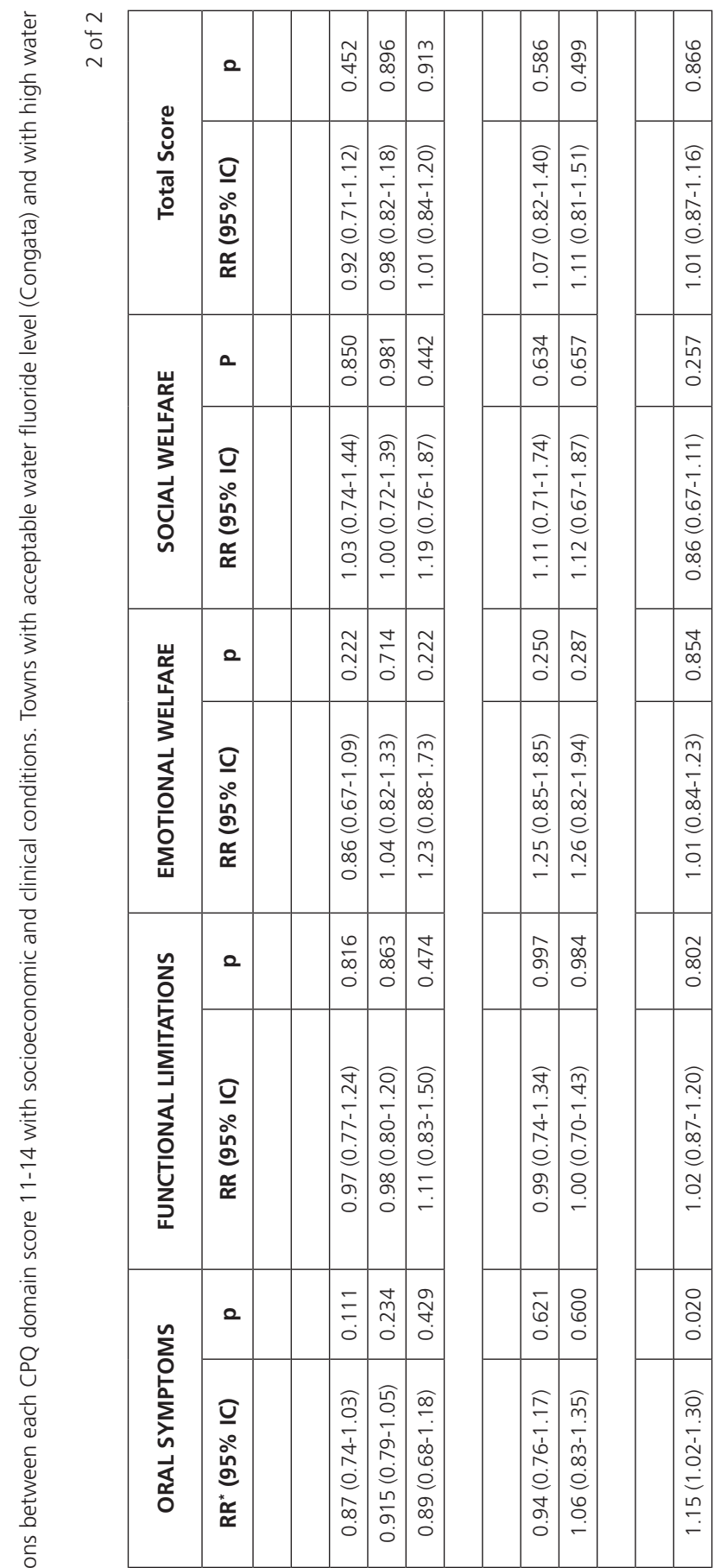

岗

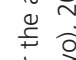

市



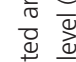

裹敦



产

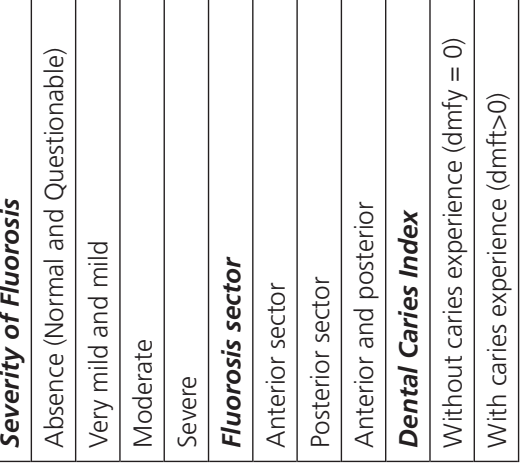

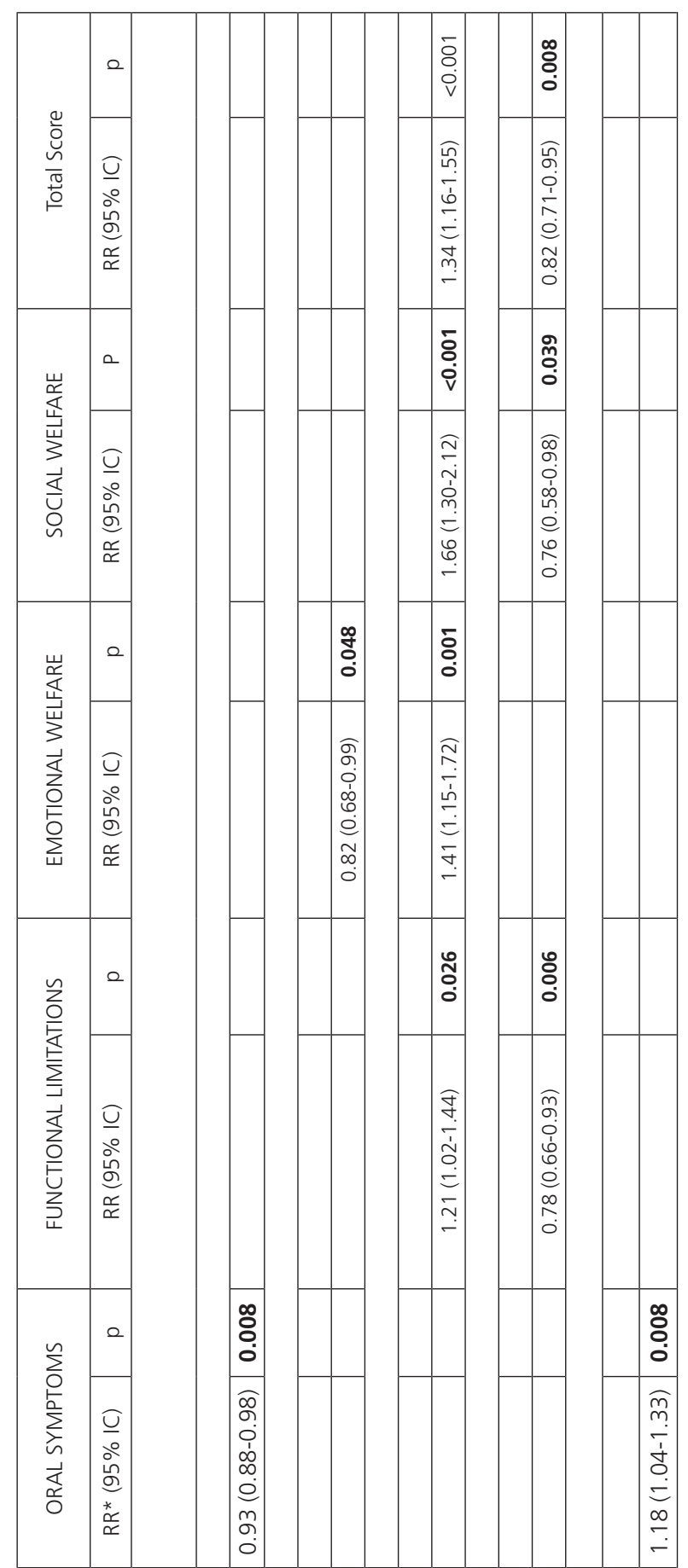

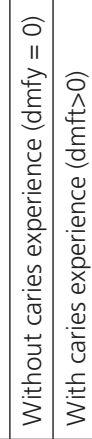


oral symptoms domain $(R R=0.93 ; P=0.008$ and $R R=1.18$; $\mathrm{P}=0.008$, respectively). Children from private school showed a negative impact on all the domains, with exception of the symptoms domain $(P<0.01)$. Mother's education showed a positive impact on all the domains, with exception of the symptoms domain and emotional welfare domain $(P<0.01)$.

\section{DISCUSSION}

The prevalence of dental fluorosis found (75\%) might be considered very high. The fact that fluoride level found in water does not justify this very high dental fluorosis prevalence and severity, it leads to the hypothesis that the public water should not be the etiological factor. Therefore, there must be other etiological factors for the occurrence of dental fluorosis that still need to be investigated.

One possible explanation for the very high prevalence of dental fluorosis could be the association of two fluoridated systemic sources like public water and salt consumption. However, the reality is that in Peru there is no supervision by the Ministry of Health on the control of fluoridated salt. It is known that in the market there is only one trademark of fluoridated salt and its consumption is very low. Thus, it is possible to suspect that the fluoridated salt consumption associated with fluoridated public water consumption should not be the main etiological factors.

As the children are habitual residents of the towns of Congata and Uchumayo, and in these towns, there are expressive activities of minerals extraction, a possible etiological factor for very high dental fluorosis prevalence and severity might be the environmental contamination caused by mining operations.

Some studies have indicated that mining operations involve a high degree of environmental disturbance due to mineral extraction causing social, cultural and health impacts. These activities cause environmental contamination such as of the air, surface water and groundwater, posing health hazards such as dental fluorosis [16].

Apart from that, fluorides are widely distributed in the air, soil, rocks and water $[17,18]$. Exposure to fluorides might occur through food ingestion, through the skin and through respiration [19].

As respiration is a vital necessity, the contaminated air by mining operations might be the most available source of fluorides, therefore dental fluorosis through inhalation may be occurring in the studied population, but that is only a hypothesis that needs to be checked.

Thus, other epidemiological studies need to be carried out to better investigate the etiological factors that cause this very high dental fluorosis prevalence and severity found in the sample.

Depending on the severity, dental fluorosis has aesthetic and psychological consequences. It may cause tooth fractures, enamel loss, pain in different degrees. Moreover, it might negatively affect feeding quality, chewing function and need a complex restorative and aesthetic treatment [20].

In the present study, some children with moderate and severe scores $(43.08 \%)$ of dental fluorosis had enamel loss causing aesthetic problems and few tooth fractures, Interesting to notice that despite the clinical condition of the problem, there was no impact on children's OHRQoL.

Considering that the self-perception of dental fluorosis depends on the unsightly effect and degree of severity of the individuals a contradictory result was observed, which can be explained by the fact of the general condition in the children investigated who presented fluorosis in $75 \%$ of cases. Therewith one hypothesis for explaining these results is that adolescents living in a context with very similar dental appearance of their peers build a sense of identity different than other populations, which can influence in their OHRQoL perception. Future studies should be performed to better understand the etiological factors involved in the development of dental fluorosis, with the severity characteristics that were observed in the children of the present study, and to propose a form of surveillance to avoid future cases.

\section{CONCLUSION}

In conclusion, the prevalence of dental fluorosis was very high with a predominance of moderate and severe degrees. Dental fluorosis had no impact on quality of life related to oral health.

\section{Collaborators}

ZM de CALDERÓN participated in the data collection and writing the manuscript.; J ABANTO, GS OLIVEIRA and AE HADDAD participated in the study design, contributed to the data 
analysis and reviewing the manuscript; M BÖNECKER supervised all stages of research from conception and design of the project, writing and final revision of the text. All authors reviewed the text and approved its final version.

\section{REFERENCES}

1. Buzalaf M, Aparecido Cury J. and Whitford G. Fluoride exposures and dental fluorosis: a literature review. Rev FOB. 2001;9:1-10. https://doi.org/10.1590/S0034-89102002000 700015

2. Whelton HP, Spencer AJ, Do LG, Rugg-Gunn AJ. Fluoride Revolution and Dental Caries: Evolution of Policies for Global Use. J Dent Res. 2019 Jul;98(8):837-846. https://doi. org/10.1177/0022034519843495

3. Weyant RJ. Seven Sistematic Review confirm topical fluoride therapy is effective in preventing dental caries. J Evid Based Dent Pract. 2004;3:129-135. https://doi.org/10.1016/j.jebdp. 2004.03.021

4. Khan A, Moola MH, Cleaton-Jones P. Global trends in dental fluorosis from 1980 to 2000: a systematic review. SADJ. 2005 Nov;60(10):418-21.

5. Buzalaf MA, Barbosa CS, Leite Ade L, Chang SR, Liu J, CzajkaJakubowska A, Clarkson B. Enamel crystals of mice susceptible or resistant to dental fluorosis: an AFM study. J Appl Oral Sci. 2014 Jun;22(3):159-64. https://doi.org/10.1590/1678-775720 130515

6. Ministerio de Salud del Perú. Prevalencia nacional de caries dental, fluorosis del esmalte y urgencia de tratamiento en escolares de 6 a 8, 10, 12 y 15 años, Perú 2001-2002. Oficina General de Epidemiología del MINSA-Perú. Lima: MINSA; 2005. p. 18-32.

7. Aguilar-Díaz FC, Irigoyen-Camacho ME, Borges-Yáñez SA. Oral-health-related quality of life in schoolchildren in an endemic fluorosis area of Mexico. Qual Life Res. 2011 Dec;20(10):1699-706. https://doi.org/10.1007/s11136-0119897-4

8. Onoriobe U, Rozier RG, Cantrell J, King RS. Effects of enamel fluorosis and dental caries on quality of life. J Dent Res. 2014 Oct;93(10):972-9. https://doi.org/10.1177/0022034514548705

9. Lima L, Dantas-Neta N, Moura W, Moura M, Mantesso A, Moura L, et al. Impact of dental fluorosis on the quality of life of children and adolescentes Impacto da fluorose dentária na qualidade de vida de crianças e adolescentes. Rev odontol UNESP. 2014; 43(5): 326-332. https://doi.org/10.1590/rou.2014. 052

10. Chankanka O, Levy SM, Warren JJ, Chalmers JM. A literature review of aesthetic perceptions of dental fluorosis and relationships with psychosocial aspects/oral health-related quality of life. Community Dent Oral Epidemiol. 2010 Apr;38(2):97-109. https://doi.org/10.1111/j.1600-0528.2009. 00507.x

11. Abanto J, Albites U, Bönecker M, Martins-Paiva S, Castillo JL, Aguilar-Gálvez D. Cross-cultural adaptation and psychometric properties of the Child Perceptions Questionnaire 11-14 (CPQ11-14) for the Peruvian Spanish language. Med Oral Patol Oral Cir Bucal. 2013 Nov 1;18(6):e832-8. https://doi. org/10.4317/medoral. 18975

12. Abanto J, Carvalho TS, Mendes FM, Wanderley MT, Bönecker M, Raggio DP. Impact of oral diseases and disorders on oral health-related quality of life of preschool children. Community Dent Oral Epidemiol. 2011 Apr;39(2):105-14. https://doi. org/10.1111/j.1600-0528.2010.00580.x

13. Trujillo C, Arias-Barahona H. y Zenteno J. Elementos del geosistema de las canteras de sillar, Añashuayco Arequipa. Universidad Nacional San Agustin 2008 [citado 2017 Fev 5]. Disponible em: <http://carlostrujillove.blogspot.com. br/2008/12/geosistema-ashuayco.html>.

14. World Health Organization. WHOQOL - measuring quality of life. The World Health Organization quality of life instruments. Geneva: World Health Organization; 1997.

15. Knutson JW. An index of the prevalence of dental caries in school children. Public Health Rep 1944, 59(8): 253-263. https://doi.org/10.1590/S0034-89101990000500009

16. Shreerup G, Madhumita D, Guru B. Environmental degradation due to exploitation of mineral resources: a scenario in Orissa. The Bioscan. 2010;2:295-304.

17. Peckham S, Awofeso N. Water fluoridation: a critical review of the physiological effects of ingested fluoride as a public health intervention. ScientificWorldJournal. 2014 Feb 26;2014:293019. https://doi.org/10.1155/2014/293019

18. Gómez del Solar S. El flúor en odontología preventiva. Talleres Gráficos de Valparaiso. 2da Edición. Año 1991.

19. Kanduti D, Sterbenk P, Artnik B. FLUORIDE: A REVIEW OF USE AND EFFECTS ON HEALTH. Mater Sociomed. 2016 Apr;28(2):133-7. https://doi.org/10.5455/msm.2016.28.133137

20. Moysés SJ, Moysés ST, Allegretti AC, Argenta M, Werneck R. Fluorose dental: ficção epidemiológica? [Dental fluorosis: epidemiological fiction?]. Rev Panam Salud Publica. 2002 Nov;12(5):339-46. Portuguese. https://doi.org/10.1590/s10 20-49892002001100008

Received on: 10/7/2020 Approved on: 10/12/2020 